\title{
Healthcare technology and technology assessment
}

\section{James H. Herndon · Raymond Hwang •}

K. J. Bozic

Published online: 18 July 2007

(C) Springer-Verlag 2007

\section{Erratum to: Eur Spine J \\ DOI 10.1007/s00586-007-0369-z}

The given name of the third author was rendered incorrectly. The correct spelling is K. J. Bozic as given here.

The online version of this article can be found under doi:10.1007/ s00586-007-0369-z.

J. H. Herndon $(\bowtie) \cdot$ R. Hwang Department of Orthopaedic Surgery,

Massachusetts General Hospital,

55 Fruit Street, Boston, MA 617-367-5117, USA

e-mail: jherndon@partners.org

K. J. Bozic

Department of Orthopaedic Surgery

and Institute for Health Policy Studies,

School of Medicine, University of California,

San Francisco, CA, USA 